\title{
Signs and symptoms of temporomandibular disorders in instrumental performers
}

\author{
Jae-Young Jang', Young-Chan Choi', Jung-Hee Bae², Seong-Taek Kim* \\ 'Department of Orofacial Pain \& Oral Medicine, College of Dentistry, Yonsei University, Seoul, Republic of Korea \\ ${ }^{2}$ Division in Anatomy and Developmental Biology, Department of Oral Biology, College of Dentistry, Yonsei University, Seoul, \\ Republic of Korea
}

Purpose: The aim of the study was to evaluate the subjective symptoms and clinical signs through the TMD-questionnaire, clinical examination and radiography against the many instrumental performers and to investigate the association between playing instruments and TMDs. Materials and Methods: A total of 803 instrumental performers received TMD-related questionnaire and evaluations of prevalence and disease distribution were performed. Among those who reported at least one symptom of TMD, 70 volunteers visited in clinic then received clinical examination and radiography for diagnosis and evaluations of prevalence and disease distribution were performed. 70 subjects were divided into three groups as woodwind, brass wind, string. Comparative analysis of disease distribution was performed. Results: Among 803 instrumental performers, 610 people (75.97\%) were reported to one or more symptoms of TMD. The most frequent symptom was click (29.68\%).70 subjects underwent a clinical examination and radiography survey results, the most frequent symptom was a click (29.75\%). Most commonly diagnosed disease was a myofacial pain (30.53\%).Comparison of the three groups, a significant difference was not observed in the clinical sign. But among subject symptom, muscle pains howed significant differences in accordance with the Group $(P=0.024)$. During the 70 people who underwent clinical examination, 66 people (94.3\%) showed moderate to severe attrition, mild to severe tongue ridging, mild to severe cheek ridging assigns of parafunction. Conclusion: Instrumental performers showed a high prevalence of TMD and the most of the musicians with temporomandibular disorder had bruxism or clenching habits. (J Dent Rehabil Appl Sci 2015;31(2):86-95)

Key words: instrumental performers; musicians; temporomandibular disorders (TMDs)

\begin{abstract}
서론
측두하악장애는 저작근, 턱관절과 주변 경조직 및 연 조직의 문제를 포함하는 광범위한 임상적 문제이다. ${ }^{1}$ 측 두하악장애의 증상으로 하악운동범위의 감소, 저작근의 통증, 턱관절의 통증, 턱관절잡음, 개구 시 기능제한이나 변위 등이 있으며, ${ }^{1}$ 가장 흔한 증상은 저작근이나 귀 앞 쪽 부위의 통증이고, 두통 또한 측두하악장애 환자에서
\end{abstract}

*Correspondence to: Seong-Taek Kim

Professor, Department of Orofacial Pain \& Oral Medicine, College of Dentistry, Yonsei University, 50 Yonsei-ro, Seodaemun-gu, Seoul, 120-752, Republic of Korea Tel: +82-2-2228-3110, Fax: +82-2-393-5673, E-mail: k8756050@yuhs.ac.kr

Received: April 6, 2015/Last Revision: May 6, 2015/Accepted: May 31, 2015
흔히 볼 수 있다..$^{2-8}$ 측두하악장애의 역학은 다양한 요소 에 의해 이루어진다. 신경근육학적, 신경생물학적, 생체 역학적, 생물 심리사회적 요인들이 측두하악장애를 야 기할 수 있으며, ${ }^{9}$ 이갈이나 이악물기, 껌씹기 등과 같은 부기능성습관들은 측두하악장애 발생 위험을 증가시킨 다. ${ }^{10-13}$ 과거 선학들의 연구에서 측두하악장애의 유병률 은 $30 \%$ 에서 $39.2 \%$ 정도로 다양하게 보고되었다. ${ }^{14-17}$

측두하악장애는 생활습관이나 직업적 특성과 밀접한 
관계가 있는데 특히 턱이나 입을 많이 사용하고 두경부 근육을 긴장된 상태로 유지하는 경향이 있는 악기 연주 자들에게 자주 나타나는 것으로 보고되고 있으며, 또한 이들은 업무와 관련된 높은 물리적, 심리학적 요구사항 들 때문에 다양한 건강문제가 발생할 위험을 가지고 있 다. ${ }^{18}$ 악기연주자들의 구강안면문제에는 측두하악장애 라 일컬어지는 두개하악장애도 포함된다. ${ }^{19}$ Steinmetz 등 $^{19}$ 은 베를린과 작센안할트 오케스트라 악기연주자 408명을 대상으로한 설문지검사 결과에서 두개하악장 애가 흔하고 악기연주자의 절반 정도가 구강안면문제를 가진다고 보고하였으며 JaanaHeikkilä 등 ${ }^{20}$ 은 핀란드 오 케스트라 악기연주자 73명을 대상으로 한 설문지결과 에서 연주자들 중 $56 \%$ 가 적어도 하나 이상의 측두하악 장애와 관련된 증상을 가지고 있었다고 보고했다.

악기 연주자의 자세와 연주하는 악기의 종류는 직업 적 질환을 결정한다. ${ }^{21}$ 어깨와 턱을 이용하여 지지하는 현악기나 관악기를 연주하는 것은 안면 근골격계의 저 작근에 과부하를 주어 측두하악장애를 발생시키거나 이 미 존재하는 측두하악장애를 더 악화시킬 수 있다. ${ }^{22}$

오랜 기간의 바이올린이나 관악기 연주는 두개하악장 애를 유발시킬 수 있다. ${ }^{23} \mathrm{Hirsch}$ 등 $^{24}$ 은 15 명의 바이올린 연주자와 51명의 비올라 연주자들을 대상으로 설문지 검사 및 턱의 움직임을 기록한 결과, 이들이 치과대학생 집단에 비해 턱관절음, 턱관절통, 최대개구제한 등 측두 하악장애와 관련된 증상 및 징후를 더 보인다고 보고하 였다. Rodríguez-Lozano 등 ${ }^{25}$ 은 41명의 바이올린 연주자 들에게 설문지검사, 임상검사, 방사선검사를 시행한 결 과, 바이올린 연주자는 대조군에 비해 최대 개구 시 통 증, 부기능성습관, 턱관절잡음 등을 더 많이 보인다고 보고하였다.

목관악기나 금관악기 연주자들에서는 하악을 후상방 으로 움직여 턱관절에 압박을 주게 되는 특수한 연주 기 법을 볼 수 있는데, 이는 턱관절에 직접적인 영향을 주어 측두하악장애를 발생시키는 데에 기여한다. ${ }^{26}$ 관악기 연 주는 많은 호흡과 많은 구강안면근육 활동을 요구하는
복합적인 신경근육학적 활동으로, ${ }^{27,28}$ 레바논에서 시행 된 설문지검사 결과에서는, 340 명의 관악기 연주자들 중 $23 \%$ 가 측두하악장애에 이환 되어 있음을 보고하였다. ${ }^{29}$

이처럼 악기연주와 측두하악장애의 연관성에 관한 연 구들이 있어왔으나 이전의 연구들은 주관적인 증상을 바탕으로 한 설문지에 의한 것이 대부분이었고 그 모집 단의 크기도 작았다. 또한 임상검사와 방사선검사를 병 행한 연구도 있었으나 그마저도 모집단의 크기가 작고, 관악기나 바이올린, 비올라 등 특정한 악기연주자에 한 해서 이루어진 연구라는 한계점들을 가지고 있었다.

본 연구의 목적은 다양한 종류의 악기연주자로 이루어 진 많은 대상자를 상대로 설문지검사, 임상검사 및 방사 선검사를 시행하여 측두하악장애와 관련된 주관적 증상 과 임상적 징후들을 평가하고, 이를 토대로 악기연주와 측두하악장애의 연관성에 대해 알아보고자 함에 있다.

\section{연구 재료 및 방법}

\section{1. 연구 대상}

악기연주를 전공으로 하는 예술고등학교학생, 대학 생, 오케스트라 단원 803명을 상대로 측두하악장애에 대한 설문지를 작성하게 하였으며, 답변은 복수응답이 가능하도록 했다. 803명이 연주하는 악기의 종류는 바 순, 클라리넷, 플루트, 오보에, 대금, 호른, 튜바, 색소폰, 트럼펫, 트롬본, 첼로, 바이올린, 비올라, 더블베이스, 하 프, 타악기, 키보드, 피아노 등이었다. 803명의 측두하악 장애증상 유병률을 조사하였고 그 분포를 살펴보았으 며, 한가지 이상의 측두하악장애 증상을 보고한 연주자 중에서 70 명의 자원자를 연세대학교 치과병원 구강내 과에 내원시켜 임상검사 및 방사선검사를 시행하고 객 관적인 진단을 내려(Fig. 1) 질환의 분포를 확인하였다.

70 명 대상자는 목관악기 연주자 18명(대금1명, 바순3 명, 오보에5명, 클라리넷2명, 플루트7명), 금관악기 연주 자 13 명(튜바2명, 트럼펫7명, 트롬본2명, 호른2명), 현악

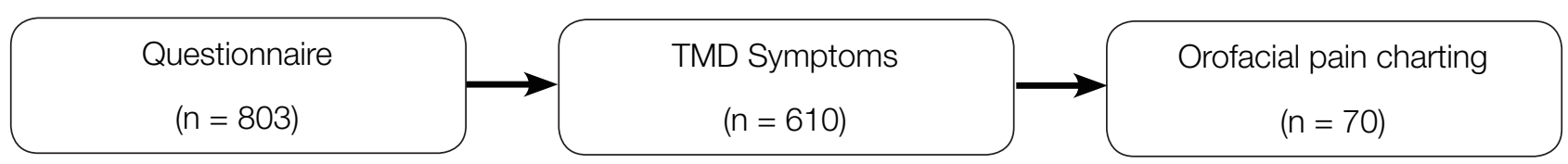

Fig. 1. Flow chart. 
Table 1. Instruments distribution of 70 subjects who participated in clinical examination

\begin{tabular}{lc}
\hline \multicolumn{2}{c}{ Subjects demography $(\mathrm{n}=70)$} \\
\hline Wind instrument & 18 \\
Brass wind instrument & 13 \\
String instrument & 39 \\
\hline
\end{tabular}

기 연주자 39명(바이올린29명, 비올라7명, 첼로2명, 더 블베이스1명)의 세 집단으로 분류되었으며(Table 1), 각 집단에 따른 질환분포를 살펴보고 비교평가 하였다. 임 상검사와 방사선검사는 1 인의 검사자가 시행하였다.

\section{2. 연구 방법}

\section{1) 설문지검사}

설문지는 6 개의 질문으로 구성되었다(Table 2). ${ }^{17}$

\section{2) 임상검사}

임상검사는 저작근과 턱관절의 촉진, 턱관절음 검사, 하악운동범위(maximum mouth opening, protrusion, lateral movement) 검사, 치아의 교모, 설측면과 협점막 의 압흔에 대한 평가를 포함하여 이루어졌으며, 저작근 과 턱관절의 통증은 0 부터 10 까지 visual analog scale를 이용하여 표시하도록 했다.

\section{3) 방사선검사}

파노라마 방사선사진 촬영과 경두개 방사선사진 촬영 을 시행하였다.

\section{3. 통계학적 분석}

설문지에 응한 803명의 연령, 연주기간과 임상검사, 방사선검사를 병행한 70명의 연령, 연주기간, 하루 연습 시간의 평균값과 표준편차를 산출하였다. 70 명의 주관 적 증상과 임상적 징후의 분포를 악기 종류별집단에 따 라 비교하기 위해 chi-square test 가 이용되었다.

모든 통계분석은SPSS software package 21.0 (IBM Corp., Armonk, NY, USA)를 사용하여 수행되었다. 통 계적 유의 수준은 $P<0.05$ 로 산정되었다.

\section{결과}

설문지검사에 응답한 803명은 남자 185명, 여자 618 명으로 구성되었다. 이들의 연령은 15 세부터 55 세로 평 균 연령은 $24.2 \pm 6.8$ 세였다. 평균연주기간은 $12.0 \pm$ 7.2년이었다. 그 들 중 610 명 $(75.97 \%)$ 에서 적어도 하 나 이상의 측두하악장애와 관련된 증상을 보고하였다. 설문지검사에서 가장 많이 보고된 증상은 단순관절음 (click)으로서 전체 증상의 $29.68 \%$ 를 차지했다. 그 다 음으로는 기타 두통이 의심되는 증상 $(17.56 \%)$, 턱관절 통(16.07\%), 근육통(13.60\%), 편두통이 의심되는 증상

Table 2. The contents of the questionnaire

\section{TMD questionnaire}

1. Have you ever had pain in the joint around your ears?

2. Have you ever had pain around your cheeks, temple, or jaw?

3. Have you ever been aware of noises when you open or close your jaw?

1) click

2) crepitus

4. Have you ever had any difficulty opening your mouth?

5. Do you have parafunction such as bruxism or clenching?

6. Have you had a headache?

1) Aspects of pain : throbbing / tightening

2) Site of pain

3) Frequency of pain

4) Intensity of pain

5) Accompanying symptoms : nausea, vomiting, photophobia, phonophobia, headache worsening if climb or go down the stairs 


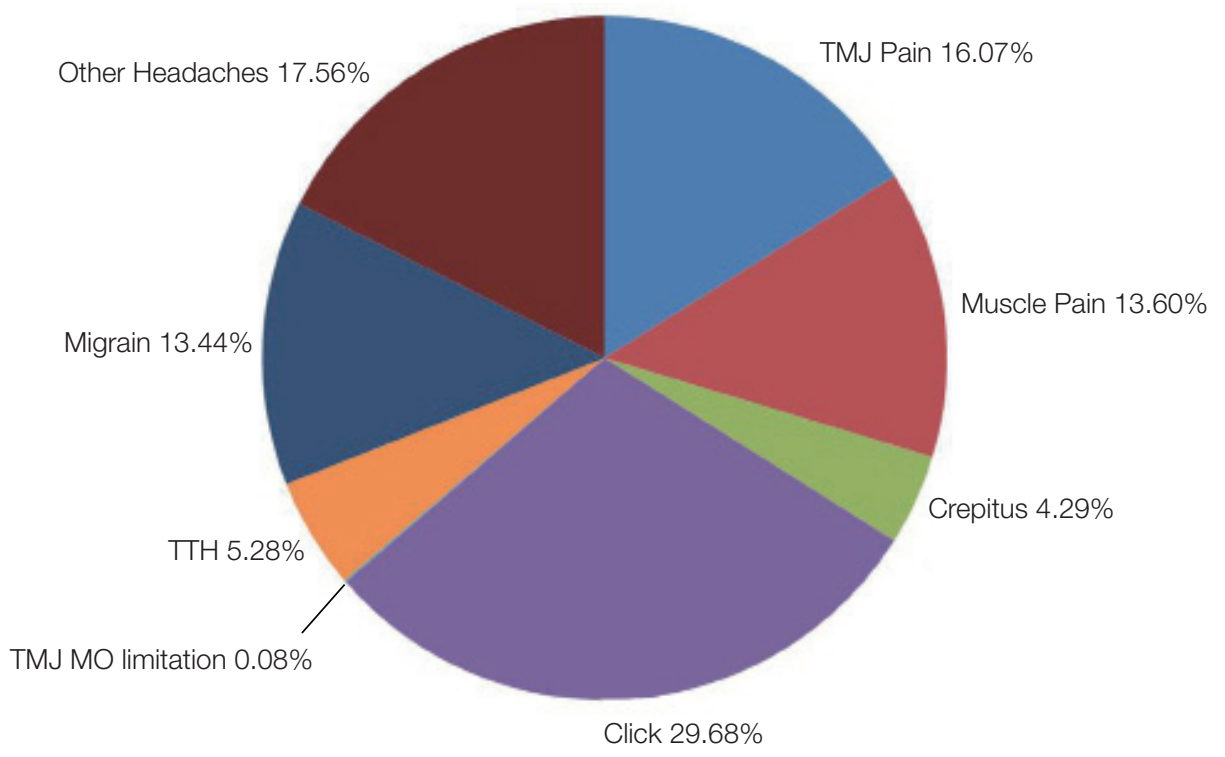

Fig. 2. Distribution of subjective symptom in 803 subjects. TTH, tension-type headache; MO, mouth opening.

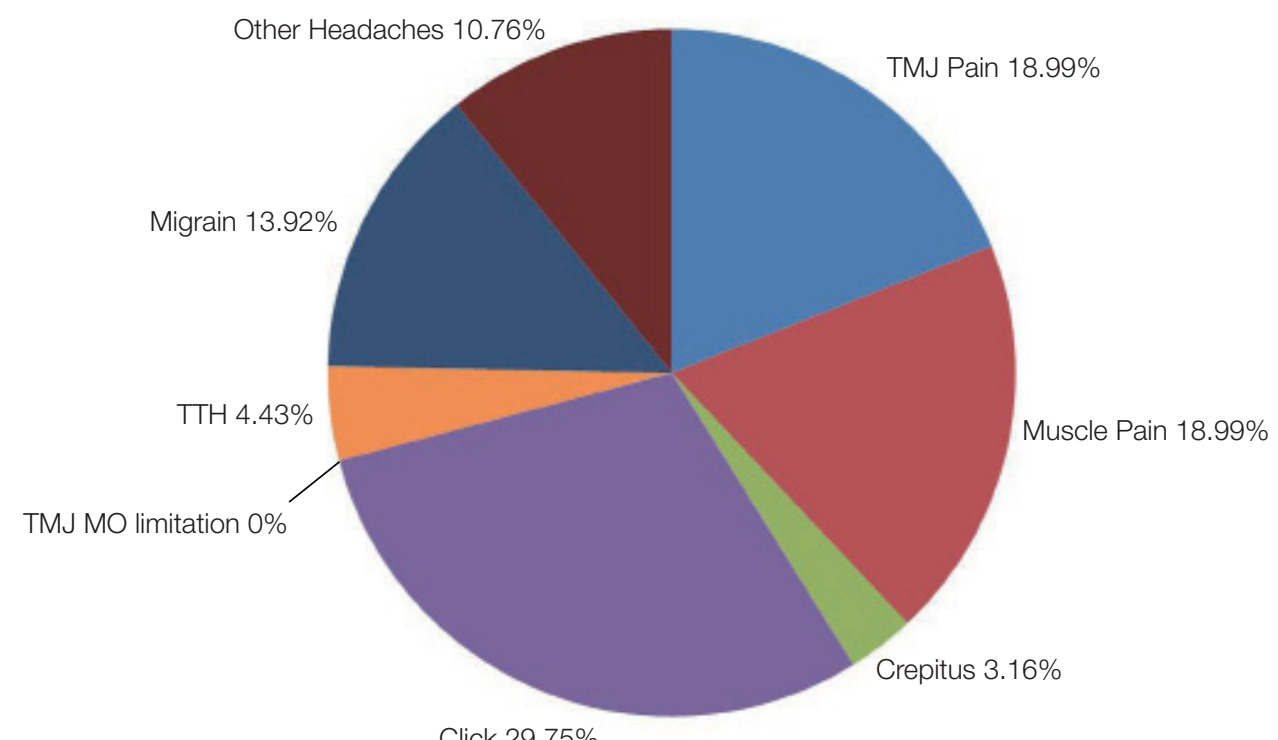

Click $29.75 \%$

Fig. 3. Distribution of subjective symptom in 70 subjects. $\mathrm{TTH}$, tension-type headache; MO, mouth opening.

(13.44\%), 긴장형 두통이 의심되는 증상 $(5.28 \%)$, 염발음 (4.29\%), 개구제한 $(0.08 \%)$ 순으로 뒤를 이었다(Fig. 2). 803명 중 193명(24.03\%)은 아무런 증상이 없다고 보고 하였다.

임상검사 및 방사선검사를 병행한 70 명은 남자 9 명, 여자 61명으로 구성되었다. 이들의 연령은 17세부 터 53세로 평균연령은 $25.0 \pm 6.9$ 세였다. 평균연주기간
은 $12.9 \pm 6.4$ 년이었고, 하루 평균연습시간은 $3.9 \pm 1.5$ 시간이었다. 70 명의 설문지검사에서 가장 많이 보고 된 증상도 단순관절음으로 전체 증상의 $29.75 \%$ 를 차 지했다. 그 다음으로는 턱관절통과 근육통이 $18.99 \%$ 로 같았으며, 편두통이 의심되는 증상 $(13.92 \%)$, 기타 두통이 의심되는 증상 $(10.76 \%)$, 긴장형 두통이 의심되 는 증상 $(4.43 \%)$, 염발음(3.16\%)이 뒤를 이었다(Fig. 3 ). 
객관적인 임상검사 및 방사선검사 결과 가장 많이 진 단된 질환은 근막동통 $(30.53 \%)$ 이었고 정복성관절원판 변위(27.89\%), 턱관절통(22.63\%), 편두통(10.00\%), 기 타두통 $(3.16 \%)$, 턱관절골관절염 또는 턱관절골관절증
(3.16\%), 긴장형두통 $(2.10 \%)$, 비정복성 관절원판변위 $(0.53 \%)$ 가 뒤를 이었다(Fig. 4$)$.

70 명의 악기 그룹에 따른 주관적 증상과 객관적 임상 징후의 분포는 Table 3,4 와 같다(Table 3,4$).^{20}$

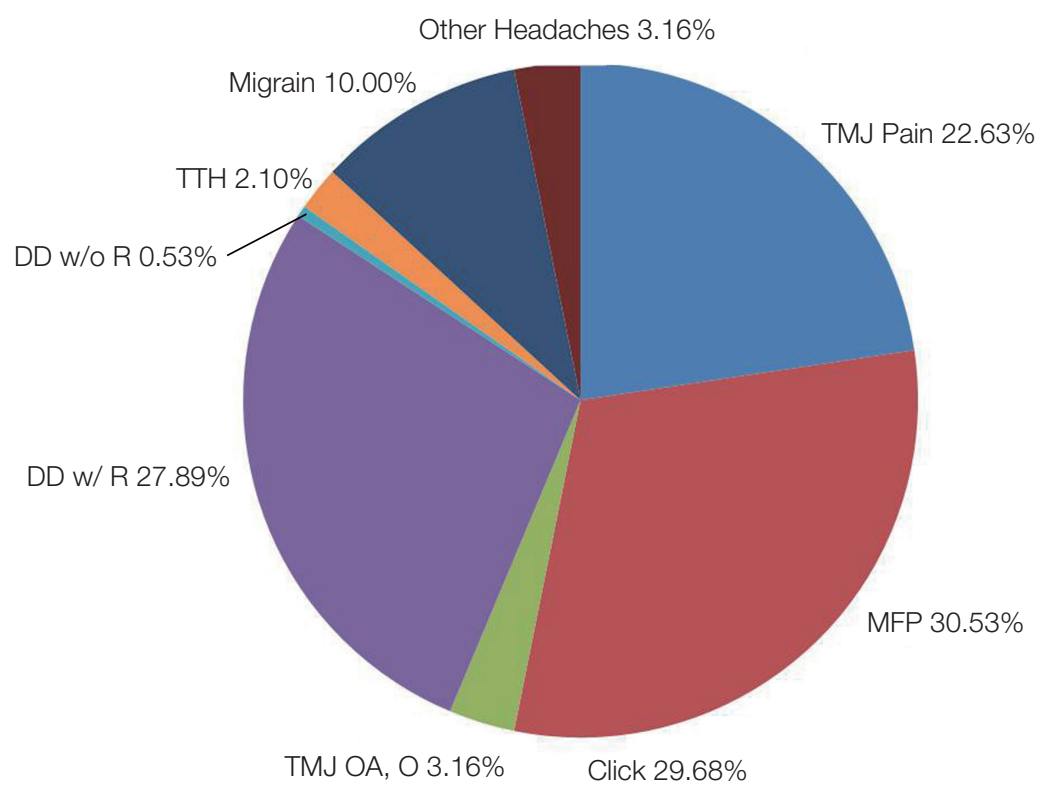

Fig. 4. Distribution of clinical sign in 70 subjects.

TTH, tension-type headache; DD w/o R, disk displacement without reduction; DD w/ R, disk displacement with reduction; TMJ OA, O, TMJ osteoarthritis, osteoarthrosis; MFP, myofacial pain.

Table 3. Proportions of subjective symptoms of TMDs according to the instrument played

\begin{tabular}{|c|c|c|c|c|c|c|c|c|c|}
\hline Instruments & $\mathrm{n}$ & $\begin{array}{c}\text { TMJ pain } \\
\mathrm{n}(\%)\end{array}$ & $\begin{array}{c}\text { Muscle pain } \\
\text { n }(\%)\end{array}$ & $\begin{array}{c}\text { Crepitus } \\
\text { n }(\%)\end{array}$ & $\begin{array}{l}\text { Click } \\
\mathrm{n}(\%)\end{array}$ & $\begin{array}{c}\mathrm{MO} \\
\text { limitation } \\
\mathrm{n}(\%)\end{array}$ & $\begin{array}{l}\text { TTH } \\
\text { n }(\%)\end{array}$ & $\begin{array}{c}\text { Migraine } \\
\mathrm{n}(\%)\end{array}$ & $\begin{array}{c}\text { Other } \\
\text { headaches } \\
\mathrm{n}(\%)\end{array}$ \\
\hline Wood wind & 18 & $10(55.6)$ & $9(50.0)$ & $2(11.1)$ & $15(83.3)$ & $1(5.6)$ & $2(11.1)$ & $7(38.9)$ & $2(11.1)$ \\
\hline Brass wind & 13 & $6(46.2)$ & $4(30.8)$ & $1(7.7)$ & $10(76.9)$ & $0(0.0)$ & $1(7.7)$ & $6(46.2)$ & $1(7.7)$ \\
\hline String & 39 & $20(51.3)$ & $28(71.8)$ & $3(7.7)$ & $30(76.9)$ & $0(0.0)$ & $4(10.3)$ & $9(23.1)$ & $12(30.8)$ \\
\hline Total & 70 & $36(51.4)$ & 41 (58.6) & $6(8.6)$ & $55(78.6)$ & $1(1.4)$ & $7(10.0)$ & $22(31.4)$ & $15(21.4)$ \\
\hline
\end{tabular}

MO, mouth opening; TTH, tension-type headache.

Table 4. Proportions of clinical signs of TMDs according to the instrument played

\begin{tabular}{cccccccccc}
\hline \multirow{2}{*}{ Instruments } & & $\begin{array}{c}\text { TMJ } \\
\text { Arthralgia }\end{array}$ & MFP & TMJ OA,O DD w/ R & DD w/o R & TTH & Migraine & $\begin{array}{c}\text { Other } \\
\text { headaches }\end{array}$ \\
& $\mathrm{n}$ & $\mathrm{n}(\%)$ & $\mathrm{n}(\%)$ & $\mathrm{n}(\%)$ & $\mathrm{n}(\%)$ & $\mathrm{n}(\%)$ & $\mathrm{n}(\%)$ & $\mathrm{n}(\%)$ & $\mathrm{n}(\%)$ \\
\hline Wood wind & 18 & $13(72.2)$ & $16(88.9)$ & $2(11.1)$ & $13(72.2)$ & $1(5.6)$ & $1(5.6)$ & $3(16.7)$ & $2(11.1)$ \\
Brass wind & 13 & $9(69.2)$ & $9(69.2)$ & $1(7.7)$ & $8(61.5)$ & $0(0.0)$ & $0(0.0)$ & $6(46.2)$ & $0(0.0)$ \\
String & 39 & $21(53.8)$ & $33(84.6)$ & $3(7.7)$ & $32(82.1)$ & $0(0.0)$ & $3(7.7)$ & $10(25.6)$ & $4(10.3)$ \\
Total & 70 & $43(61.4)$ & $58(82.9)$ & $6(8.6)$ & $53(75.7)$ & $1(1.4)$ & $4(5.7)$ & $19(27.1)$ & $6(8.6)$ \\
\hline
\end{tabular}

MFP, myofacial pain; TMJ OA, O, TMJ osteoarthritis, osteoarthrosis, DD w/ R, disk displacement with reduction; DD w/o R, disk displacement without reduction; TTH, tension-type headache. 
Table 5. Frequency and expected frequency of muscle pain of 70 subjects

\begin{tabular}{clccc}
\hline & & \multicolumn{2}{c}{ (Subjective symptom) } & Muscle Pain \\
& & No & Yes & Total \\
\hline \multirow{2}{*}{ Wood wind } & Frequency & 9 & 9 & 18 \\
& Expected frequency & 7.5 & 10.5 & 18.0 \\
\multirow{3}{*}{ Brass wind } & Frequency & 9 & 4 & 13 \\
& Expected frequency & 5.4 & 7.6 & 13.0 \\
& Frequency & 11 & 28 & 39 \\
& Expected frequency & 16.2 & 22.8 & 39.0 \\
& Frequency & 29 & 41 & 70 \\
& Expected frequency & 29.0 & 41.0 & 70.0 \\
\hline
\end{tabular}

세 그룹을 비교 시, 임상적 징후에서는 유의할 만한 차 이가 발견되지 않았으나 주관적 증상에서는 근육통에서 현악기 연주자가 유의성 있게 높게 나타났다 $(P=0.024)$ (Table 5).

70 명의 임상검사 결과 66 명 $(94.3 \%)$ 에서 이갈이나 이 악물기 같은 부기능성습관의 징후인 중등도에서 중증의 치아교모, 경증에서 중증의 설측면 압흔, 경증에서 중증 의 협점막 압흔을 보였다.

\section{고찰}

본 연구의 목적은 다양한 종류의 악기 연주자로 이루 어진 많은 대상자를 상대로 설문지검사, 임상검사 및 방 사선검사를 시행하여 측두하악장애와 관련된 주관적 증 상뿐 아니라 임상적 징후들을 판단하여 악기 연주와 측 두하악장애의 연관성에 대해 알아보는 것이었다.

803명의 설문지 결과 610명 (75.97\%)에서 하나 이상 의 측두하악장애 증상을 보고하였다. 이를 통해 악기연 주자가 아닌 일반인의 유병률보다 더 높은 수치임을 알 수 있었다. ${ }^{14-17}$ 임상검사 및 방사선검사를 병행한 70 명의 설문지 결과 가장 많이 보고된 주관적 증상은 단순관절 음 및 염발음을 포함하는 턱관절음 $32.91 \%)$ 이었으나 임 상검사 및 방사선검사 결과 가장 많이 발견된 임상적 징 후는 근막동통 $(30.53 \%)$ 이었다. 70 명의 $58.6 \%$ 에서 근육 통증을 호소한 것에 비해 실제 임상검사 시 근막동통의 유병률은 $82.9 \%$ 에 달했다. 이는 악기연주자들이 스스로 근육의 통증을 잘 인지하지 못하고 있다는 것을 시사한 다. 이는 적절한 치료나 관리가 늦어져 측두하악장애를 더 악화시키는 요인이 될 것으로 추측된다.
악기 그룹간 비교 시, 임상적 징후에서는 유의할 만 한 차이가 나타나지 않았으나 주관적 증상에서는 근육 통에서 현악기 연주자가 유의성 있게 높게 나타났다 $(P$ $=0.024)$. 현악기 연주자에서 근육통의 유병률이 높은 것을 볼 수 있었는데 이는 악기연주 시의 자세와 관련 이 있을 것으로 예상된다. Kovero와 Könönen ${ }^{30,31}$ 의 연 구에 의하면 몸의 한쪽으로 악기를 놓고 연주하는 방식 때문에 한 쪽 구강안면부위에 통증이 생길 수 있음을 알 수 있다. 바이올린이나 비올라 연주자는 대조군에 비해 더 많은 측두하악장애 징후를 보이고 ${ }^{24,25,30}$ 물리적인 과 부하를 받아 구강안면부위에 질환을 갖는 것으로 보인 다. ${ }^{32}$ 또한 이들에게서는 턱을 반대 쪽 턱관절 방향으로 미는 경향을 볼 수 있는데, ${ }^{24,33}$ 턱으로 악기를 지지하여 안정시킴으로써 연주자들의 턱에는 악기위치와 반대방 향의 압력이 가해져 반대측 턱관절에 물리적인 스트레 스를 야기하게 된다. ${ }^{34}$ 바이올린과 비올라 연주자의 두 개하악장애 빈도는 $74 \%$ 까지 보고되고 있으며, ${ }^{24,25,30,35}$ 턱 관절의 조기 퇴행성 변화와 안면골격구조의 변화 사례 도 보고된 바 있다. ${ }^{36,37}$

70 명 중 금관악기 연주자에서는 편두통의 비율이 다 소 높은 것을 볼 수 있는데, 이는 금관악기의 연주 기법 특성상 산소포화도가 낮아져 편두통 발생 비율이 높아 지는 것을 의심해 볼 수 있다. 하지만 악기 그룹에 따른 편두통 유병률에서 통계적으로 유의성 있는 차이는 나 타나지 않았다. 이는 금관악기 그룹의 모집단이 13명으 로 설문대상자 수가 부족한 것이 한계점이 되었을 것으 로 예상되며 차후 후속 연구가 필요해 보인다.

악기연주자가 되는 것은 계속적인 기술의 향상과 많 은 시간의 연습이 요구된다. ${ }^{23}$ 악기연주자는 특별한 인 
내와 끈기를 보여야 하며 매일의 연주 연습이 필수적이 다. ${ }^{23}$ 오랜 기간의 집중과 목, 턱, 얼굴 근육에 가해지는 반복적인 힘은 악구강계(stomatognathic system)의 변 형을 초래하며, ${ }^{23}$ 좋지 않은 자세와 근육 긴장 상태로 악 기를 연주할 때 측두하악장애 증상이 활성화되고 더 두 드러지는 것으로 보인다. ${ }^{38}$ 스트레스와 비-인체공학적인 활동은 정신적 긴장과 신체적 질환의 발생에 기여하는 데, 악기연주자들은 이를 과소평가하거나 감추고 휴식 과 병원치료가 요구되는 신호를 무시하기도 하며 ${ }^{21}$ 이로 인해 결과적으로 악기연주자들에게서는 측두하악장애 증상이 더 늘어나게 된다. ${ }^{20}$

Franco 등 ${ }^{39}$ 은 대조군에 비해 측두하악장애집단에서 두통이 더 흔하다고 보고하였다. 편두통이 가장 흔한 유형이었고 다음으로 긴장형두통과 기타 두통이 뒤를 이었다. 이와 유사하게 우리의 연구에서도 편두통이 가 장 많이 진단되었다.

이갈이나 이악물기, 껌씹기 등의 부기능성습관들은 측두하악장애 발생 위험을 증가시키는데 ${ }^{10-13}$ 우리의 연 구에서 임상검사와 방사선검사를 받은 70 명 중에 66명 (94.3\%)에서 이갈이나 이악물기 같은 부기능습관의 징 후인 중등도 이상의 치아교모, 설측면 압흔, 협점막 압 흔을 볼 수 있었다.

본 연구의 한계는 모집단의 평균연령이 20대로 젊다 는 것이고 대부분 여성이라는 점이다. 연구에 많은 수 의 악기연주자들이 포함되었지만 20 대의 수가 많고 여 성의 수가 많다는 점이 결과를 편향되게 할 여지가 있 으며, 일반적으로도 측두하악장애는 젊은 사람, 여성에 서 더 호발하는 것으로 알려져 왔다. 측두하악장애는 남 성보다 여성에서 1,5 - 2배 더 호발하고, 측두하악장애 로 치료를 받은 환자의 $80 \%$ 가 여성이라고 알려진 바 있 다. ${ }^{40}$ 그렇기 때문에 원래 측두하악장애의 유병률이 높 은 집단을 대상으로 한 연구의 결과이므로 이것이 단순 히 악기연주에 의한 것인지 연령이나 성별도 영향을 주 었는지 명확히 구분하기 어려운 한계점이 있다. 악기연 주를 하지 않는 일반인들의 연령과 성별에 따른 측두하 악장애 유병률과 본 연구와의 비교분석이 필요해 보인 다.

Kovero 등 ${ }^{41}$ 은 바이올린 연습시간이 늘어날수록 측 두하악장애 징후가 늘어난다고 보고하였다. 그러나 Rodríguez-Lozano 등 ${ }^{25}$ 은 바이올린 연주자에서 연습시 간과 측두하악장애 발생 사이에 차이점을 발견하지 못 하였고 연주기간과 측두하악장애와의 연관성도 발견하
지 못하였다고 보고하였다. 추후에 악기 연주자들의 연 령, 성별, 연주기간, 일일 연습시간 등에 따른 측두하악 장애 유병률에 관한 연구들이 더 필요할 것으로 보인다.

\section{결론}

1. 803 명의 악기 연주자의 설문지검사 결과: 610 명 (75.97\%)에서 적어도 하나 이상의 측두하악장애 증상을 보고하였다. 가장 많이 보고된 증상은 단순 관절음 $(29.68 \%)$ 이었다.

2. 측두하악장애 증상을 가진 70 명의 악기 연주자의 검사 결과: 설문지검사에서 가장 많이 보고된 증 상은 단순관절음 $(29.75 \%)$ 이었다. 임상검사 및 방 사선검사 결과 가장 많이 진단된 질환은 근막동통 (30.53\%)이었다. 70명 중 66명(94.3\%)에서 이갈이 나 이악물기 같은 부기능성습관의 징후를 보였다.

3. 금관악기, 목관악기, 현악기 연주자 집단에 따른 주 관적 증상, 임상적 징후의 비교평가: 객관적 임상 징후에서는 악기의 종류에 따른 유의할 만한 차이 가 발견되지 않았으나 주관적 증상에서는 근육통 증에서 현악기 연주자가 유의성 있게 높게 나타났 다 $(P=0.024)$.

\section{Orcid}

Jae-Young Jang http://orcid.org/0000-0001-6238-5151

Young-Chan Choi http://orcid.org/0000-0001-7992-131X Jung-Hee Bae http://orcid.org/0000-0002-9058-3494

Seong-Taek Kim http://orcid.org/0000-0001-9506-5103

\section{References}

1. Wadhwa S, Kapila S. TMJ disorders: future innovations in diagnostics and therapeutics. J Dent Educ 2008;72:930-47.

2. Drangsholt M, Le Resche L. Temporomandibular disorder pain. In: Crombie IK, Croft PR, Linton SJ, Le Resche L, Von Korff M, editors. Epidemiology of pain. Seattle, WA; IASP Press; 1999. p. 203-33.

3. McNeill C. Management of temporomandibular disorders: concepts and controversies. J Prosthet Dent 1997;77:510-22.

4. Salonen L, Helldén L, Carlsson GE. Prevalence of 
signs and symptoms of dysfunction in the masticatory system: an epidemiologic study in an adult Swedish population. J Craniomandib Disord 1990; 4:241-50.

5. Dando WE, Branch MA, Maye JP. Headache disability in orofacial pain patients. Headache 2006;46: 322-6.

6. Ballegaard V, Thede-Schmidt-Hansen P, Svensson P, Jensen R. Are headache and temporomandibular disorders related? A blinded study. Cephalalgia 2008;28:832-41.

7. Graff-Radford SB. Temporomandibular disorders and headache. Dent Clin North Am 2007;51:12944.

8. Glaros AG, Urban D, Locke J. Headache and temporomandibular disorders: evidence for diagnosticand behavioural overlap. Cephalalgia 2007;27:5429.

9. Suvinen TI, Reade PC, Hanes KR, Könönen M, Kemppainen P. Temporomandibular disorder subtypes according to self-reported physical and psychosocial variables in female patients: a reevaluation. J Oral Rehabil 2005;32:166-73.

10. Karibe H, Goddard G, Gear RW. Sex differences in masticatory muscle pain after chewing. J Dent Res 2003;82:112-6.

11. Rossetti LM, Pereira de Araujo Cdos R, Rossetti $\mathrm{PH}$, Conti PC. Association between rhythmic masticatory muscle activity during sleep and masticatory myofascial pain: a polysomnographic study. J Orofac Pain 2008;22:190-200.

12. Miyake R, Ohkubo R, Takehara J, Morita M. Oral parafunctions and association with symptoms of temporomandibular disorders in Japanese university students. J Oral Rehabil 2004;31:518-23.

13. Winocur E, Gavish A, Finkelshtein T, Halachmi M, Gazit E. Oral habits among adolescent girls and their association with symptoms of temporomandibular disorders. J Oral Rehabil 2001;28:624-9.

14. Nekora-Azak A, Evlioglu G, Ordulu M, Işsever H. Prevalence of symptoms associated with temporomandibular disorders in a Turkish population. J Oral Rehabil 2006;33:81-4.

15. Goulet JP, Lavigne GJ, Lund JP. Jaw pain prevalence among French-speaking Canadians in Québec and related symptoms of temporomandibular disorders. J Dent Res 1995;74:1738-44.

16. Pow EH, Leung KC, McMillan AS. Prevalence of symptoms associated with temporomandibular disorders in Hong Kong Chinese. J Orofac Pain 2001; 15:228-34.

17. Gonçalves DA, Dal Fabbro AL, Campos JA, Bigal ME, Speciali JG. Symptoms of temporomandibular disorders in the population: an epidemiological study. J Orofac Pain 2010;24:270-8.

18. Foxman I, Burgel BJ. Musician health and safety: Preventing playing-related musculoskeletal disorders. AAOHN J 2006;54:309-16.

19. Steinmetz A, Zeh A, Delank KS, Peroz I. Symptoms of craniomandibular dysfunction in professional orchestra musicians. Occup Med (Lond) 2014;64:17-22. doi: 10.1093/occmed/kqt148. Epub 2013 Dec 11.

20. Heikkilä J, Hamberg L, Meurman JH. Temporomandibular disorders: symptoms and facial pain in orchestra musicians in Finland. Music and Medicine 2012;4:171-6. DOI: 10.1177/1943862112445796.

21. Zuskin E, Schachter N, Kolcić I, Polasek O, Mustajbegović J, Arumugam U. Health problems in musicians: a review. Acta Dermatovenerol Croat 2005;13:247-51.

22. Attallah MM, Visscher CM, van Selms MK, Lobbezoo F. Is there an association between temporomandibular disorders and playing a musical instrument? A review of literature. J Oral Rehabil 2014;41:532-41. doi: 10.1111/joor.12166. Epub 2014 Apr 5.

23. Głowacka A, Matthews-Kozanecka M, Kawala M, Kawala B. The impact of the long-term playing of musical instruments on the stomatognathic system - review. Adv Clin Exp Med 2014;23:143-6.

24. Hirsch JA, McCall WD Jr, Bishop B. Jaw dysfunction in viola and violin players. J Am Dent Assoc 1982;104:838-43.

25. Rodríguez-Lozano FJ, Sáez-Yuguero MR, BermejoFenoll A. Prevalence of temporomandibular disorder-related findings in violinists compared with control subjects. Oral Surg Oral Med Oral Pathol Oral Radiol Endod 2010;109:e15-9.

26. Gualtieri PA. May Johnny or Janie play the clarinet? 
The Eastman Study: a report on the orthodontic evaluations of college-level and professional musicians who play brass and woodwind instruments. Am J Orthod 1979;76:260-76.

27. Howard JA, Lovrovich AT. Wind instruments: their interplay with orofacial structures. Med Probl Perform Art 1989;4:59-72.

28. Prensky HD, Shapiro GI, Silverman SI. Dental diagnosis and treatment for musicians. Spec Care Dentist 1986;6:198-202.

29. Sayegh Ghoussoub M, Ghoussoub K, Chaaya A, Sleilaty G, Joubrel I, Rifaï K. Orofacial and hearing specific problems among 340 wind instrumentalists in Lebanon. J Med Liban 2008;56:159-67.

30. Kovero O, Könönen M. Signs and symptoms of temporomandibular disorders and radiologically observed abnormalities in the condyles of the temporomandibular joints of professional violin and viola players. Acta Odontol Scand 1995;53:81-4.

31. Kovero O, Könönen M. Signs and symptoms of temporomandibular disorders in adolescent violin players. Acta Odontol Scand 1996;54:271-4.

32. Steinmetz A, Ridder PH, Methfessel G, Muche B. Professional musicians with craniomandibular dysfunctions treated with oral splints. Cranio 2009;27:221-30.

33. Herman E. Orthodontic aspects of musical instrument selection. Am J Orthod 1974;65:519-30.

34. Okner M, Kernozek T, Wade M. Chin rest pressure in violin playing: musical repertoire, chin rests and shoulder pads as possible mediators. Med Probl Perf Art 1997;12:112-21.

35. Steinmetz A, Ridder PH, Reichelt A. Craniomandibular dysfunction and violin playing: prevalence and the influence on head and neck muscles in violinists. Med Probl Perform Art 2006;21:183-9.

36. Kovero O. Degenerative temporomandibular joint disease in a young violinist. Dentomaxillofac Radiol 1989;18:133-5.

37. Kovero O, KönönenM, Pirinen S. The effect of professional violin and viola playing on the bony facial structures. Eur J Orthod 1997;19:39-45.

38. Taddey JJ. Musicians and temporomandibular disorders: prevalence and occupational etiologic considerations. Cranio 1992;10:241-4.

39. Franco AL, Gonçalves DA, Castanharo SM, Speciali JG, Bigal ME, Camparis CM. Migraine is the most prevalent primary headache in individuals with temporomandibular disorders. J Orofac Pain 2010;24:287-92.

40. LeResche L. Epidermiology of temporomandibular disorders: implications for the investigation of etiologic factors. Crit Rev Oral Biol Med 1997;8:291305.

41. Kovero O, Könönen M, Pirinen S. The effect of violin playing on the bony facial structures in adolescents. Eur J Orthod 1997;19:369-75. 


\section{악기연주자의 측두하악장애 징후와 증상}

\section{장재영 ${ }^{1}$, 최영찬 ${ }^{1}$, 배정희 ${ }^{2}$, 김성택 ${ }^{1 *}$}

${ }^{1}$ 연세대학교 치과대학 구강내과학교실

${ }^{2}$ 연세대학교 치과대학 구강생물학교실

목적: 이 연구의 목적은 다양한 종류의 악기연주자를 대상으로 설문지검사, 임상검사 및 방사선검사를 시행하여 측두 하악장애와 관련된 주관적 증상 및 임상적 징후를 평가하고, 이를 토대로 악기 연주와 측두하악장애의 연관성에 대해 알아보는 것이다.

연구 재료 및 방법: 803명의 악기연주자를 대상으로 측두하악장애에 대한 설문지검사를 시행하여 대상자가 느끼는 주 관적 증상의 유병률과 분포를 살펴보고, 그 중 한가지 이상의 측두하악장애와 관련된 증상을 보고한 사람들 중 70 명의 자원자를 진료실에 내원시켜 임상검사 및 방사선검사를 시행하여 임상적 징후의 유병률과 분포를 살펴보았다. 70 명의 대상자는 목관악기 연주자, 금관악기 연주자 그리고 현악기 연주자의 세 군으로 나누어 각 군에 따른 질환 분포를 살펴 보고 비교평가 하였다.

결과: 803 명의 악기연주자 중 610명 $(75.97 \%)$ 이 한가지 이상의 측두하악장애 관련 증상을 가지고 있었다. 설문지검사 에서 가장 많이 보고된 증상은 단순관절음으로 전체 증상의 $29.68 \%$ 를 차지했다. 지원자 70 명의 객관적인 임상검사 및 방사선검사 결과 가장 많은 진단명은 근막동통으로 전체 진단의 $30.53 \%$ 를 차지하였다. 악기종류에 따라, 비교 시, 객 관적 임상 징후에서는 유의할 만한 차이가 발견되지 않았으나 주관적 증상에서는 근육통에서 현악기 연주자가 유의성 있게 높게 나타났다 $(P=0.024) .70$ 명의 임상검사 결과 66 명 $(94.3 \%)$ 에서 이갈이나 이악물기 같은 부기능성습관의 징후 를 보였다.

결론: 악기연주자에서 측두하악장애가 높은 유병률을 보였으며 측두하악장애를 가진 악기연주자들은 대부분 이갈이 나 이악물기 같은 부기능성습관을 가지고 있었다.

(구강회복응용과학지 2015;31 (2) :86-95)

주요어: 악기연주자; 측두하악장애

*교신저자: 김성택

(120-752) 서울특별시 서대문구 연세로 50 연세대학교 치과대학 구강내과학교실

Tel: 02-2228-3110 | Fax: 02-393-5673 | E-mail: k8756050@yuhs. ac. kr

접수일: 2015년 4월 6일 | 수정일: 2015년 5월 6일 | 채택일: 2015년 5월 31일 